\title{
The Use of Horizontal Representation in Students' Science Book on Energy Subject Matter and its Impact on Students' Critical Thinking Skills and Visual Literacy
}

\author{
Tyas Kharimah Tindani ${ }^{1}$, Dewi Lengkana ${ }^{2}$, M. Setyarini ${ }^{3}$, Tri Jalmo ${ }^{4}$ \\ \{datatyas@gmail.com ${ }^{1}$, dewilengkana76@gmail.com², m.setyarini@ fkip.unila.ac.id ${ }^{3}$ \} \\ Science Education, Magister Program ,Lampung University ${ }^{1}$, Biology Education, Lampung \\ University $^{2}$, Chemistry Education, Lampung University ${ }^{3}$
}

\begin{abstract}
The purpose of this study was to identify the use of horizontal representation in the students' science books in explaining scientific concepts, theories, and phenomena on energy in living system and its impact on students' critical thinking skills and visual literacy. This study was conducted on a hundred junior high schools students in Bandar Lampung city and used quantitatively descriptive method. The data were collected using questionnaires and an assessment sheet. The result showed that learning material mostly used by students was student's science books published by Indonesia's Ministry of Education and Culture in 2017 which in the very high category (97\%). The type of horizontal representation that mostly presented was image, which in the very high category $(82.8 \%$ ), while the others type of horizontal representation were in the very low category. The percentage of student activities and evaluation in the student book which in line with critical thinking skill indicators was in the medium category, and which in line with the visual literacy indicators was in the very low category $(10 \%)$.
\end{abstract}

Keywords: Horizontal Representation, Critical thinking skill, Visual literacy.

\section{Introduction}

This digital era presents opportunities as well as challenges in every aspect of life [1]. Massive developments in technology and information occur in various aspects of our life [2]. The most noticeable development happens in visual information technology [1]. Today's students live as global consumers of that visual information, but not many of them understand the information that they received [3],[5]. In dealing with this condition, students need to have good visual literacy to interpret the information they received. Visual literacy is the ability to create and interpret visual representations of data that can help students sort out the information, solve problems, and make decisions based on that information [6].

Besides having good visual literacy, students need higher-order thinking skills such as critical thinking skills to protect themselves from various false information. Critical thinking and visual literacy are the must have skills for students on this $21^{\text {st }}$ century according to the goals of the 2013 curriculum. In the 2013 curriculum, students are required to have several skills including Critical Thinking Skills, Communication Skills, Creativeness, and Collaboration. Not only that, but students are also expected to develop their talents, character, competence, and literacy so that they can face the challenges of this era [7]. It is possible to train critical thinking 
skill and visual literacy through science learning, especially on learning transformation of energy in living system [8],[9]. However, in reality, students are not easily attracted to science as a school subject [10]. It is because some scientific concepts and phenomena in science are too abstract and difficult to understand by students and this is the cause of students' lack of understanding of various concepts in science learning [11]. The low quality of science learning in Indonesia can be seen in the results of PISA and TIMSS. Since the beginning of its participation in 1999 (TIMSS) and 2000 (PISA), Indonesia has never even been in the top 30 [12].

On energy in living system topic, students are require to analyze the concept of energy transformations that occur in daily life, for example, cellular respiration and photosynthesis. Students need to understand how energy transferred through sun light into chemical energy while carbon dioxide and water are transformed into glucose and oxygen, and how energy is stored during photosynthesis. How humans and other living things process their food into energy. This topic involves several complex steps, but the details of these steps are often missing in student's science book [13]. This is one of the reason for student's difficulty on understanding the processes and phenomena that occur in the transformation of energy in living systems. It is even more difficult to understand if the explanations in the student's book are only in the form of written explanations.

Horizontal representation can be a tool to help student understand the concept of energy transformation. Horizontal representation is from the visualizable concrete objects to the underlying concept represented by more abstract such graphs, tables, equations, animation, or verbal descriptions [14]. Visual information such as pictures, tables, graphics, and animation makes brain easier to create the mental images of an action. This is very important for students who are learning a new skill. Seeing a simulation of the skill will help the brain identify the action state and then mentally simulate the actions required to put the skill into practice. The brain then stores mental simulations in memory as memory traces that can reactivated when students recall it [15]. This is why visual information tends to attract more attention than plain text, because it communicates more information, and is easier to remember $[16,4]$. This is consistent with the dual coding theory, the information in the form of visual and verbal representations are easier to remember than the textual information [17].

Visual learning plays a very important role in developing critical thinking and visual literacy. Visualization i.e. horizontal representation used to encourage learning levels and support different learning styles and to develop critical thinking in students [18]. The use of horizontal representations to visualize abstract concepts in energy in living system topic makes students understand these concepts better. The use of graphics to learn the transformation of energy will train students to be able to analyze data, make inferences, convincing arguments, and evaluate the arguments from the data [19]. For example, students learn the factors affecting the process of photosynthesis through graphics. When students have to convert information from graphics into the other forms of information, it will make students think visually. Meanwhile, students' critical thinking skills can be develop by concluding the factors based on the data from the graph. Before concluding, students have to analyze the data, it forced students to think and improve their critical thinking skills.

The purpose of this study is to identify the use of horizontal representations presented in the secondary school science books in explaining scientific concepts, theories, and phenomena on energy in life and the impact on students' critical thinking skills and visual literacy. 


\section{Materials and Method}

This study conducted on one hundred $7^{\text {th }}$ grade students from ten junior high school in the city of Bandar Lampung. This study was used a quantitatively descriptive method. The first step of this research was to find out the teaching materials mostly used by students using the questionnaires. Then, the second step was to analyze the science books that mostly used by students using the assessment sheet that was validated by the expert. The assessment sheet was used to find out the type of horizontal representation in the science book and determined its impact on critical thinking skills and visual literacy achievement based on evaluation and student's activities on the book.

Criteria for data analysis results from student questionnaires and science book analyses are present in Table 1. Analysis of science book was based on the use of horizontal representations, aspects of critical thinking skills according to indicators of critical thinking skills by Ennis and visual literacy according to the visual literacy indicators by Avgerinou [8],[20]. This study used three of the eleven visual literacy indicators by Avgerinou, which consist of visual thinking, visual reasoning, and visual associations. Indicators of critical thinking skills in this study consist of providing simple explanations, building basic skills, concluding, provide further explanation, and set strategy and tactics. The data analysis technique of the questionnaire data needs assessment of student was done by calculating the percentage of respondents' answers on each item using the following formula [21], see equation (1):

$$
\% \mathrm{~J}_{\text {in }}=\frac{\sum \mathrm{Ji}}{\mathrm{N}} \times 100 \%
$$

Where $\% \mathrm{~J}_{\text {in }}$ is the percentage of answer choices $\mathrm{i}, \sum \mathrm{Ji}$ is the number of respondents who answered answer $\mathrm{i}$, and $\mathrm{N}$ is the total number of respondents.

The data analysis technique of the science's book assessment was done by calculating the percentage using the following formula[21], see equation (2):

$$
\% \mathrm{X}_{\text {in }}=\frac{\sum \mathrm{S}}{\mathrm{Smaks}} \times 100 \%
$$

Where $\% \mathrm{X}_{\text {in }}$ is the percentage of answer choices, $\sum \mathrm{s}$ is the total score answered on assessment sheet, and $S_{\text {maks }}$ is the maximum score.

The interpretation of percentage criteria for data analysis results from student questionnaires and assessment sheets [22], is presented in Table 1.

Table 1. Interpretation of Percentages in questionnaire and assessment sheets

\begin{tabular}{cc}
\hline Percentage (\%) & Criteria \\
\hline $80,1-100$ & Very high \\
$60,1-80$ & High \\
$40,1-60$ & Medium \\
$20,1-40$ & Low \\
$0,0-20$ & Very low \\
\hline
\end{tabular}




\section{Result}

The result of the data analysis of student questionnaire data of teaching materials used by students are presented on Figure 1.

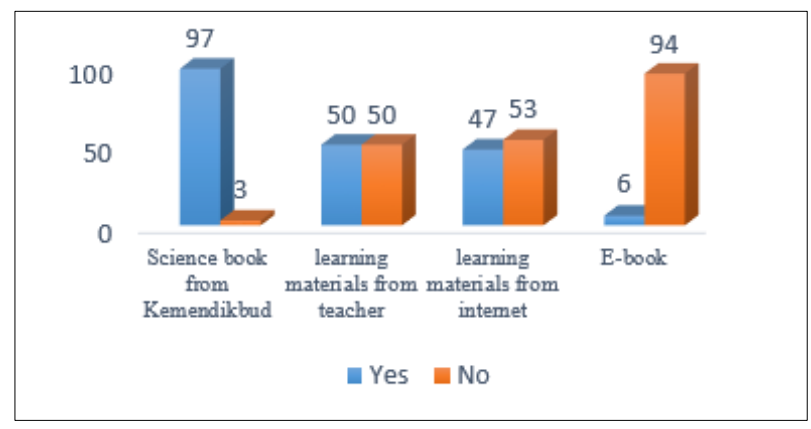

Fig. 1. Learning materials used by students in energy in living system topic

Horizontal representation analysis data of science book on energy subject matter published by the Ministry of Education and Culture in 2017 are presented on Figure 2.

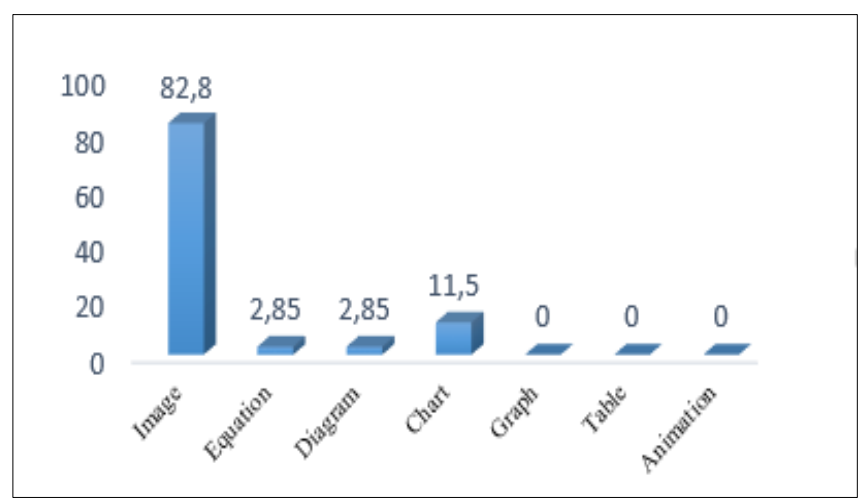

Fig. 2. Horizontal representation in the Ministry of Education and Culture's science book

The percentage of evaluation questions and student activities types presented in science book on energy subject matter presented in Figure 3. The percentage of critical thinking skills and visual literacy Indicators presented in the science book are present in Figure 4 and Figure 5. 


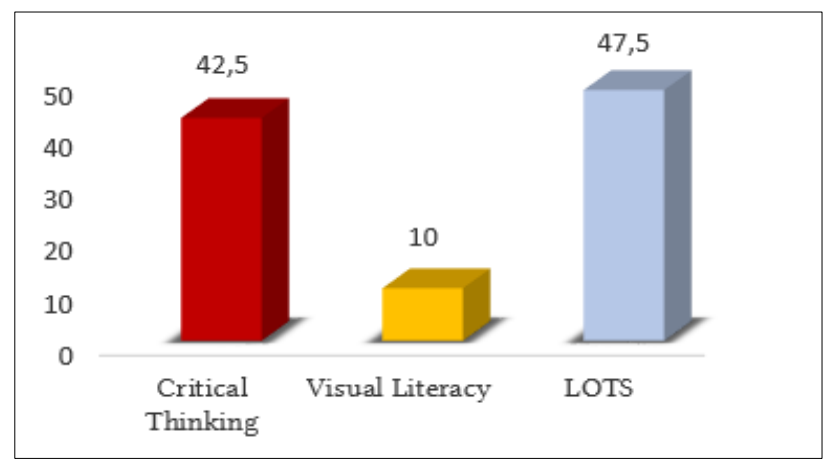

Fig. 3. Percentage of question types presented in the Ministry of Education and Culture's science book

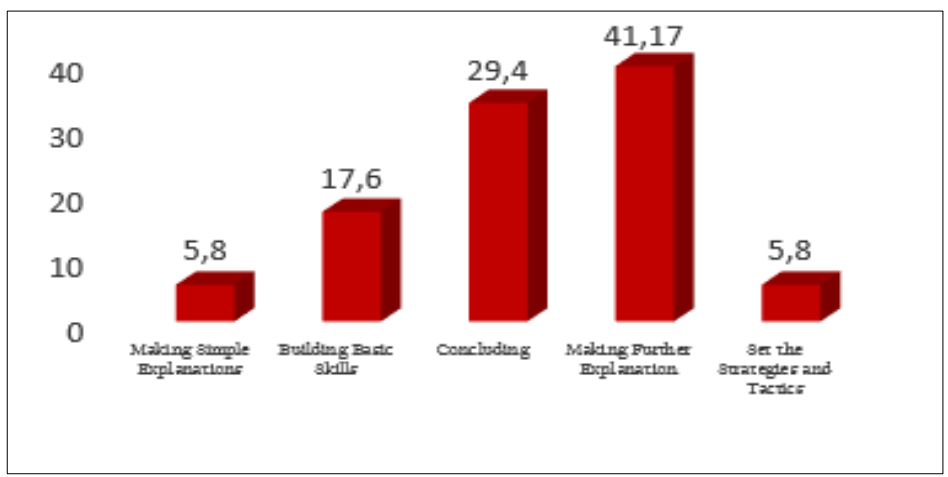

Fig. 4. Indicators of critical thinking skills presented in the Ministry of Education and Culture's science book

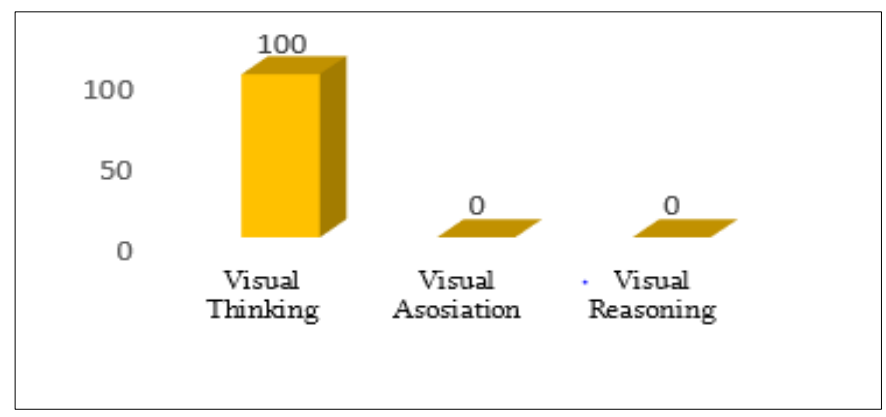

Fig. 5. Visual literacy indicators presented in the Ministry of Education and Culture's science book 


\section{Discussion}

Learning materials are all forms of material used to assist teachers in carrying out teaching and learning activities. It can be in the form of written material or unwritten material [23]. The learning material mostly used by students in leaning energy subject matter is the 2013 curriculum science book published by the Ministry of Education and Culture in 2017. This book is published in digital form (e-book) and in regular printed book form. Even though it is published in e-Book form, it does not provide interactive features and most students use it in printed form. Based on Figure 1, it can be seen that from 100 respondents, the percentage of students who use printed books published by the Ministry of Education and Culture is in the very high category (97\%), students who use teaching materials made by teachers (50\%), students who use teaching materials from the internet $(47 \%)$, while students who use e-books $(6 \%)$.

Based on Figure 2. In the science book used by students, several types of horizontal representations have been presented. Horizontal representations are represented by graphs, equations, or more abstract verbal [11]. The total number of horizontal representations used in this science book is 35 , consist of pictures, equations, diagrams, and charts. The dominant type of horizontal representation is images which is in the very high category $(82.8 \%)$, while the equations $(2.85 \%)$, diagrams $(2.85 \%)$, and charts $(11.5 \%)$ are in the very low category. Horizontal representations in the form of graphs, tables, and animations are not presented in the science book. The concept of energy transformation consists of abstract and complex scientific concepts and makes students difficult to understand [24]. Representation in science learning has an important role to help students to understand scientific concepts and phenomena[19]. Learn complicated scientific concepts using multiple forms of representation such as diagrams, graphs, and equations can bring benefits for students [25].

Critical thinking is a reflective way of thinking that makes sense or based on the logic that focuses on determining what to believe and do [26]. Critical thinking skills can be trained in science learning using the five indicators of critical thinking skill by Ennis, which consist of providing simple explanations, building basic skills, concluding, providing further explanations, and arranging strategies and tactics [8],[9],[27]. Based on Figure 3. It can be inferred that the science book from the Ministry of Education and Culture that students use to learn energy subject matter has presented the five indicators of Ennis's critical thinking skills indicators. The analysis was carried out by looking at the evaluation questions and student activities presented in the science book.

The total number of questions in the science book in energy subject matter is 40 questions, but only 4 questions in line with the visual literacy indicators [20] and 17 questions in line with the critical thinking indicators [27]. Based on Figure 4, it can be inferred that the indicators provide simple explanations $(5.8 \%)$, set strategies and tactics $(5.8 \%)$, and building basic skills $(17.6 \%)$ are in the very low category while the conclusion $(29.4 \%)$ and giving a further explanation $(41.17 \%)$ are in the low category. Although the five indicators of critical thinking skills have been presented in the science book from the Ministry of Education and Culture, but the percentage is still lower than the LOTS questions that presented in the book.

Besides critical thinking skills, visual literacy has been recognized as a necessary skill for effective learning and teaching. These skills are important and must be taught and learned by students [28]. Visual literacy can be developed as a set of skills to be able to interpret the content of visual information, examine the social impact of images, and discuss the goals found in 
images [1]. This ability can be measured using several indicators; i.e. visual thinking, visual reasoning, and visual associations. Based on Figure 5, it can be inferred that the visual literacy indicator presented in the science book is only visual thinking $(100 \%)$. Visual association and visual reasoning are not presented in the science books. Whereas visual association activities train students to connect verbal messages and visual representations to enhance the meaning, while visual reasoning trains students to think logically and coherently with visual information [20].

\section{Conclusion}

Based on the results and discussion, it can be concluded that the learning materials mostly used by students on energy subject matter is science book published by the Ministry of Education and Culture. The horizontal representation in the science book has not been optimally used to improve students' critical thinking skills and visual literacy. The use of horizontal representations can help students easier to understand abstract concepts in energy subject matter and develop students' critical skills and visual literacy. Thus, student science books should present more horizontal representations because it has impacts on the development of students' critical thinking skills and visual literacy.

\section{References}

[1] Ramadlani, A. K., Khalig, A., and Wibisono, M. Visual literacy and character education for alpha generation. Proceedings International Seminar on Language, Education and Culture Universitas Negeri Malang. 2017.

[2] Turk, V., and Bergin, M. Understanding Generation Generation Alpha. Wired Consulting. 2017. https://cnda. condenast. co. uk/wired/UnderstandingGenerationAlpha.Pdf

[3] Cheung, C.-K., and Jhaveri, A. D. Developing students' critical thinking skills through visual literacy in the New Secondary School Curriculum in Hong Kong. Asia Pacific Journal of Education. 2014. 36(3): 379-389.

[4] Fernández, B. G., and Ruiz-Gallardo, J. R. Visual literacy in primary science: exploring anatomy cross-section production skills. Journal of Science Education and Technology, 2017. 26(2), 161-174.

[5] Lowe, R. Visual Literacy and Learning in Science. ERIC Digest. 2017.

[6] Alper, B., Riche, N. H., Chevalier, F., Boy, J., \& Sezgin, M. Visualization literacy at elementary school. Proceedings of the 2017 CHI Conference on Human Factors in Computing Systems. 2017. (pp. 5485-5497). ACM.

[7] Trisdiono, H. \& Muda, W. Strategi Pembelajaran abad 21.2013. https://lpmpjogja.kemdikbud.go.id/strategi-pembelajaran-abad-21/

[8] Tilchin, O., \& Raiyn, J. Computer-Mediated Assessment of Higher-Order Thinking Development. International Journal of Higher Education. 2015. 4(1), 2 -231.

[9] Chiu, P. S., Su, Y. N., Huang, Y. M., Pu, Y. H., Cheng, P. Y., Chao, I. C., and Huang, Y. M. Interactive Electronic Book for Authentic Learning. Authentic Learning Through Advances in Technologies. 2018. (pp. 45-60).

[10] Bidarra, J., and Rusman, E. Towards a pedagogical model for science education: bridging educational contexts through a blended learning approach. Open Learning: the journal of open, distance and $e$ learning. 2017. 32(1), 6-20.

[11] Takaoglu, Z. B. Energy Concept Understanding of High School Students: A Cross-Grade Study. Universal Journal of Educational Research. 2018. 6(4), 653-660. 
[12] Nugroho, R. A. HOTS Keterampilan Berpikir Tingkat Tinggi. Jakarta. PT. Gramedia Widiarsana Indonesia. 2008.

[13] Ryoo, K., and Bedell, K. The effects of visualizations on linguistically diverse students' understanding of energy and matter in life science. Journal of Research in Science Teaching. 2017. 54(10), 1274-1301.

[14] Tsui, C. Y., and Treagust, D. F. Introduction to multiple representations: Their importance in biology and biological education. Multiple representations in biological education. Springer, Dordrecht. 2013. (pp. 3-18).

[15] St John Loker, S. Dynamic vs. static visualizations for learning procedural and declarative information (Doctoral dissertation). 2016.

[16] Adaval, R., Saluja, G., and Jiang, Y. Seeing and thinking in pictures: A review of visual information processing. Consumer Psychology Review. 2019. 2(1), 50-69.

[17] Paivio, A. Mental representations: A dual coding approach. New York: Oxford University Press; 1986.

[18] Shatri, K., and Buza, K. The Use of Visualization in Teaching and Learning Process for Developing Critical Thinking of Students. European Journal of Social Science Education and Research. 2017. 4(1), 71-74.

[19] Gilbert, J. K. Visualization: An emergent field of practice and enquiry in science education. Visualization: Theory and practice in science education. 2008. (pp. 3-24). Springer, Dordrecht;

[20] Avgerinou, M. D. Re-viewing visual literacy in the "bain d'images" era. TechTrends. 2009. 53(2), 28-34.

[21] Sudjana. Metode Statistika. Bandung. Tarsito. 2005.

[22] Arikunto. Dasar-dasar evaluasi pendidkan edisi revisi. Jakarta. Bumi Aksara. 2010.

[23] Direktorat Pembinaan Sekolah Menegah Atas. Panduan Pengembangan Bahan Ajar. Jakarta. Depdiknas. 2008.

[24] Ryoo, K., and Linn, M. C. Can dynamic visualizations improve middle school students' understanding of energy in photosynthesis?. Journal of Research in Science Teaching. 2012. 49(2), 218-243.

[25] Ainsworth, S. The educational value of multiple-representations when learning complex scientific concepts. Visualization: Theory and practice in science education. Springer, Dordrecht. 2008. (pp. 191-208).

[26] Ennis, R.H. Critical thinking across the curriculum: The wisdom CTAC program. Inquiry: Critical Thinking Across the Disciplines. 2013. 28(2), 25-45. https://doi.org/10.5840/inquiryct20132828.

[27] Ennis, R. H. The nature of critical thinking: An outline of critical thinking dispositions and abilities. Sixth International Conference on Thinking. Cambridge, MA. 2011. (pp. 1-8).

[28] Sims, E., O'Leary, R., Cook, J., and Butland, G. Visual literacy: what is it and do we need it to use learning technologies effectively?. ASCILITE. 2002 (pp. 885-888). 